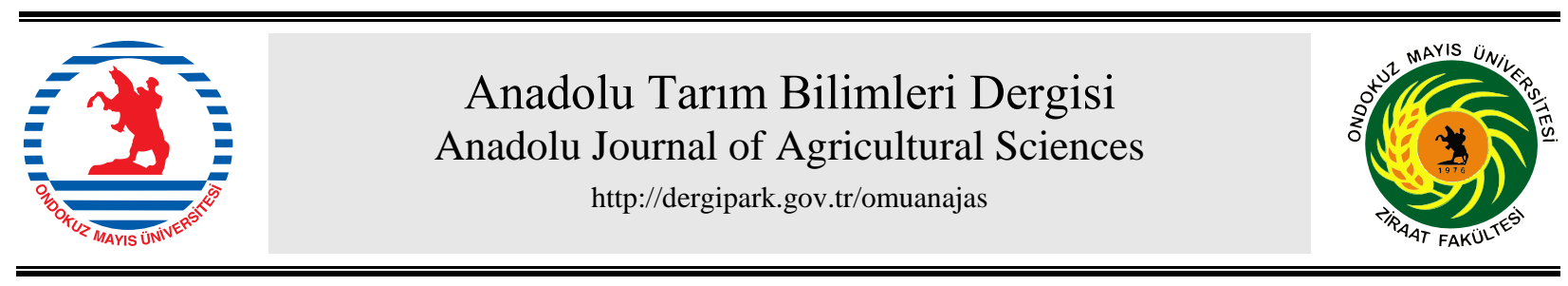

Research/Araştırma

Anadolu Tarım Bilim. Derg./Anadolu J Agr Sci, 33 (2018)

ISSN: 1308-8750 (Print) 1308-8769 (Online)

doi: 10.7161/omuanajas.449602

\title{
Determination of antioxidant and antiradical properties of Picea orientalis cone
}

\author{
Meryem Topal \\ Gumushane University, Vocational School of Health Services, Department of Medical Services and Techniques, Gumushane, Turkey \\ *Corresponding author/Sorumlu yazar: topalmeryem@hotmail.com
}

Geliş/Received 31.07.2018 Kabul/Accepted 05.10.2018

\begin{abstract}
Structural degradation of DNA, proteins, carbohydrates and lipids occurs as long as the reactive oxygen species formed in metabolism are not inhibited. As a result, both the stabilization and the function of the cell membrane are impaired and many degenerative diseases occur. In previous times, people applied to herbal remedies to solve their health problems. Today, scientific studies have increased, especially as alternative medicine has shown. Plants containing phenolic compounds are commonly used as natural antioxidants. These compounds stop or prevent the reactions caused by free radicals and prevent diseases such as heart, cancer, and lung diseases. Antioxidants are known as substances that prevent or completely stop the oxidation of biomolecules and they have use a very common. East spruce is the scientific name $P$. orientalis and it found in the family of pine trees. In this study, it was aimed to determine the antioxidant capacity by using ethanol extracts of east spruce cone. For this purpose, antioxidant and antiradical properties were determined by different bioanalytical methods in vitro such as determination of iron and copper reduction capacities, ABTS and DPPH radical scavenging activities, total phenolic and flavonoid compound amounts by using ethanol extracts of east spruce cone. The $P$. orientalis cone had an $\mathrm{IC}_{50}$ value of $24.75 \mu \mathrm{g} \mathrm{mL}^{-1}$ for DPPH radical removal activity and $13.42 \mu \mathrm{g} \mathrm{mL}^{-1}$ for ABTS radical removal activity. Accordingly, it has been determined that the methods have high antioxidant capacity.
\end{abstract}

Keywords:

Antioxidant activity

East spruce

Picea orientalis

\section{Picea orientalis kozalağının antioksidan ve antiradikal özelliklerinin belirlenmesi}

\section{ÖZET}

Metabolizmada oluşan reaktif oksijen türleri engellenmediği sürece, DNA, protein, karbohidrat ve lipitlerde yapısal bozulmalar meydana getirir. Buna bağlı olarak hücre membranının hem stabilizesi ve hem de fonksiyonları bozulur ve birçok dejeneratif hastalıklar meydana gelir. Önceki çağlarda insanlar sağlık sorunlarını çözmek için de bitkisel tedavilere başvurmuştur. Günümüzde özellikle bilimsel olarak çalışmalar artmış özellikle alternatif tıp olarak da yaygınlık göstermiştir. Fenolik bileşik içeren bitkiler doğal antioksidan olarak genellikle kullanılmaktadır. Bu bileşikler serbest radikallerin yol açtığ reaksiyonları durdurarak veya engelleyerek kalp, kanser, ve akciğer hastalıkları gibi hastalıkların oluşumuna engellerler. Antioksidanlar, biyomoleküllerin oksidasyonunu engelleyen veya tamamen durduran maddeler olarak bilinir ve oldukça yaygın bir kullanım alanına sahiptirler. Doğu ladin, çamgiller familyasında bulunan bilimsel adı P. orientalis'dir. Yapılan bu çalışmada doğu ladin kozalağının etanol ekstreleri kullanılarak antioksidan kapasitesinin belirlenmesi hedeflenmiştir. Bu amaçla demir indirgeme kapasiteleri ve bakır indirgeme kapasiteleri, ABTS radikal giderme aktiviteleri ve DPPH radikal giderme aktiviteleri, total fenolik bileşik miktarlarını ve flavonoit bileşik miktarlarını belirleme gibi in vitro şartlarda farklı biyoanalitik metotlar ile antioksidan ve antiradikal özellikleri belirlendi. P. orientalis kozalağının DPPH radikal giderme aktivitesi için $\mathrm{IC}_{50}$ değeri $24,75 \mu \mathrm{g} \mathrm{mL} \mathrm{m}^{-1}$, ABTS radikal giderme aktivitesi için ise $13,42 \mu \mathrm{g} \mathrm{mL} \mathrm{m}^{-1}$ olarak tespit edildi. Buna göre yapılan metotlarda yüksek antioksidan kapasitesine sahip olduğu belirlendi.

Anahtar Sözcükler: Antioksidan aktivite Doğu ladin Picea orientalis

\section{Introduction}

Oxidation is a chemical reaction that separates electrons from an atom or molecule. If an atom has lost its electron exchange it has undergone oxidation. It represents an important part of our metabolism and aerobic life. Because of the oxygen molecule produces energy in the form of ATP as the last electron receiver in electron transfer. A glitch in the transmission of these electrons causes serious problems (Sehitoglu et al., 2015; 
Halliwell, 1997).

Free radicals are extremely unsteady molecules. Molecules, atoms, or groups of atoms that can independently sustain their existence, containing one or more unpaired electrons, are called free radicals (Gulcin, 2009; MacDonald-Wicks et al., 2006). Free oxygen radicals (ROS) are radicals containing reactive nonradical compounds or at least one unpaired electron capable of oxidizing biomolecules (Gulcin et al., 2005). ROS such as lipid peroxide, hydrogen peroxide, hydroxyl radical, and superoxide anion are produced by many organisms in living organisms (Cakmakci et al., 2015; Halliwell and Gutteridge, 1990). Active species derived from oxygen, including free radicals, play a role in tissue damage following ischemia and reperfusion of the heart and brain. ROS occurs continuously during normal physiological events. These ROSs can easily initiate peroxidation of membrane lipids that cause lipid peroxide accumulation (Gulcin et al., 2010).

One of the most important requirements in quality life is healthy nutrition. Many pathological and physiological events lead to malnutrition as a cause metabolic changes in the body. Healthy eating is very important to protect from diseases. Besides, physical activity, not using alcohol and not smoking are important criteria for healthy and quality living (Kalin et al., 2015). Antioxidant nutrition is especially important to get rid of the effects of free radicals (Gulcin, 2011).

Picea orientalis (L.), Eastern Black Sea region of Turkey is an important species in forest ecosystems. This type is one of 50 spruce species on earth (Sonmez et al., 2007). Picea orientalis, with its pointed, smooth and plump hills, is located in the forest trees where the branches are frequent. Picea orientalis has been found to survive for a long time in low light and even in the shade. It can also be said that it is a shadow tree. It is more diffuse in moist regions (Ucarc1 and Bilir, 2018). Mature cones of oriental spruce are cylindrical or oval, with open tile color and flat flake edges. This feature can be easily distinguished from European ladies. Cones are used in lung diseases such as cough, asthma, and sputum. Cones are also used their oils and jams in the food sector (Deniz et al., 2010).

In the literature, it is known that natural antioxidants prevent the formation of diseases caused by many diseases such as myocardial infarction, cancer, and inflammatory diseases caused by ROS. Therefore, the studies for determining strong and natural antioxidants properties are increasing rapidly. We think that the obtained data will make an important contribution to the design and pharmacological applications of the drugs to be used for treatment (Gulcin et al., 2012; Valenzuela and Nieto, 1996).

Antioxidants protect the human body from the effects of free radicals as well as prevent the progression of many chronic diseases (Lai et al., 2001; Gülçin et al., 2005). Natural antioxidant alternative and reliable antioxidants of plant origin are becoming more valuable (Skerget et al., 2005). Antioxidants are used as additives in foods to prevent oxidation radical chain reactions (Gülçin et al., 2007).

Phenolic substances affect the flavor of vegetablederived foods by coloring and especially leaving a bitter taste in the mouth; is an important group of components that are often found in fruits and vegetables in very small quantities. They protect the plant against insect and animal pests. Phenolic compounds can contribute to the taste and aroma of many plant-based foods. Determination of the chemical composition of the Picea orientalis corpus; determining the bioavailability of the antioxidant capacity and antioxidant components of the determined plant; it is very important for our study to determine the nutritional properties of phenolic compounds. The results of the Picea orientalis cones are thought to lead to anticancer, antimutagenic studies.

\section{Materials and Methods}

\section{1. $\mathrm{Fe}^{3+}-\mathrm{Fe}^{2+}$ reduction capacity}

Reduction of iron was done according to the method of Oyaizu (1986). For this, a stock solution was first prepared at a concentration of $1 \mathrm{mg} \mathrm{mL}^{-1}$. This stock was transferred to the test tubes in different concentrations in the solution. Then $2.5 \mathrm{~mL}$ and $0.2 \mathrm{M}$ phosphate buffer (pH: 6.6) and $2.5 \mathrm{~mL}, 1 \%\left[\mathrm{~K}_{3} \mathrm{Fe}(\mathrm{CN})_{6}\right] \mathrm{pH}$ were added to each tube and the mixture was incubated for $20 \mathrm{~min}$ at $50^{\circ} \mathrm{C}$. Then $2.5 \mathrm{~mL}, 10 \%$ TCA was added to the reaction mixture. After addition of $0.1 \% \mathrm{FeCl}_{3}$, the final mixture was read at an absorbance of $700 \mathrm{~nm}$.

\section{2. $\mathrm{Cu}^{2+}{ }_{-} \mathrm{Cu}^{+}$reduction capacity (Cuprac method)}

The $\mathrm{Cu}^{2+}$ reduction activity was modified according to the method of Apak et al. 2006. $\mathrm{CuCl}_{2}$ solution $(0.01$ $\mathrm{M}, 0.25 \mathrm{~mL})$, neocuproine solution $\left(7.5 \times 10^{-3} \mathrm{M}, 0.25\right.$ $\mathrm{mL}$ ) and $\mathrm{CH}_{3} \mathrm{COONH}_{4}$ buffer solution (1.0 M, $0.25 \mathrm{~mL}$ ) were added to the stock solution tubes prepared at different concentrations, respectively. Absorbance values were measured at $450 \mathrm{~nm}$ after incubation.

\subsection{DPPH free radical scavenging activity}

Blois method was used for this method (1958). DPPH solution $(1 \mathrm{mM})$ was used as the free radical. A stock solution of the previously prepared concentration of $1 \mathrm{mg}$ $\mathrm{mL}^{-1}$ was used as the sample. DPPH· stock solution were added to each tube. The absorbance was measured at 517 $\mathrm{nm}$ after incubation.

\subsection{ABTS radical scavenging activity}

This method was performed according to the method of Re et al. (1999). ABTS solution was prepared as priority. ABTS radicals were produced by adding 2.45 $\mathrm{nM}$ persulphate solution to this solution. The ABTS radical scavenging activity was added at different concentrations of the designated sample. Then it was 
incubated. The absorbance was evaluated at $734 \mathrm{~nm}$.

\subsection{Determination of total phenolic compounds}

Gallic acid was used as a phenolic compound standard. For this, a standard graphic was prepared from gallic acid. Stock solution was used from the cone extracts prepared in ethyl alcohol. The stocks were taken from the solution and pipetted into meters. The final volume was completed to $23 \mathrm{~mL}$ with distilled water. Folin-Ciocalteu reactant and $2 \% \mathrm{Na}_{2} \mathrm{CO}_{3}$ were added to mixture. Samples were allowed to mix at room temperature. At the end of this time, the absorbance of the samples was read at $760 \mathrm{~nm}$. Cones extracted absorbance values corresponding to gallic acid equivalents (GAE) content was determined using the equations derived from standard graph (Bursal, 2009).

\subsection{Determination of total flavonoids}

Quercetin was used as a standard for total flavonoid concentration determination. The total flavonoid content of cone extracts was determined according to the method of Gulcin et al. (2011). For this, $1000 \mu \mathrm{g}$ extract was added to a meter. Then the extracts transferred to the test tube were vortexed by diluting with ethanol solution containing $\mathrm{CH}_{3} \mathrm{COOK}$ and $10 \% \mathrm{Al}\left(\mathrm{NO}_{3}\right)_{3}$ solutions prepared in $1 \mathrm{M}$ water. It was waited for incubation at room temperature. The absorbance was recorded at 415 $\mathrm{nm}$.

\subsection{Statistical analysis}

Each experiment was performed three times. The obtained data were recorded as mean \pm standard deviation and analyzed with SPSS (Windows 2000, version 11.5 for SPSS Inc., Chicago, IL). One-way analysis of the ANOVA type was performed using procedures. Significant differences between the averages were determined by Duncan's Multiple Range tests.

\section{Results and Discussion}

There are different compounds that have antioxidant activities in the human diet. These compounds appear to reduce the effects of ROS when looking at their structural properties. The class of compounds formed by the hydroxyl group $(-\mathrm{OH})$ attachment to the aromatic hydrocarbon ring is called phenolic compounds. They are very common in the plant kingdom, and they are found in different amounts in fruits and vegetables (Sehitoglu et al., 2015; Shahidi et al., 1992). Phenolic compounds give hydrogen in the hydroxyl groups of aromatic rings to prevent macromolecules from being oxidized by free radicals. The antioxidant effects of phenolic compounds in plants are mainly due to redox effects. For this reason, they act as reducing agents, singlet oxygen, hydrogen donors, inhibitors and metal chelates (Topal, 2014; Pagang et al., 1999).

Iron and copper reduction capacities of the $P$. orientalis cone used for this working as a natural product were found to be quite effective compared to the $\alpha$ tocopherol used as standard. The Oyaizu method was used to evaluate the $\mathrm{Fe}^{3+}-\mathrm{Fe}^{2+}$ reduction capacity of the P. orientalis cone (1986).

Table 1. Reduced ferric ions $\left(\mathrm{Fe}^{3+}\right)$ and cupric ions $\left(\mathrm{Cu}^{2+}\right)$ at $20 \mu \mathrm{g} \mathrm{mL}^{-1}$ concentration of $P$. orientalis cone and standards used in the study

\begin{tabular}{lcc}
\hline Antioxidants & $\begin{array}{c}\mathrm{Fe}^{3+} \text { reduction } \\
\left(\lambda_{700}\right)\end{array}$ & $\begin{array}{c}\mathrm{Cu}^{2+} \text { reduction } \\
\left(\lambda_{450}\right)\end{array}$ \\
\hline BHA & $1.785 \pm 0.098$ & $1.630 \pm 0.075$ \\
BHT & $0.991 \pm 0.084$ & $1.162 \pm 0.055$ \\
$\alpha$-Tocopherol & $1.021 \pm 0.002$ & $0.563 \pm 0.007$ \\
Trolox & $1.439 \pm 0.086$ & $0.875 \pm 0.031$ \\
P.orientalis cone & $0.622 \pm 0.021$ & $0.410 \pm 0.020$ \\
\hline
\end{tabular}

Examined in Table 1, P. orientalis cone showed strong $\mathrm{Fe}^{3+}$ reduction ability. The reaction shows that the increase in the $\mathrm{Fe}\left[(\mathrm{CN})_{6}\right]_{2}$ absorbance in the mixture increases due to an increase in the complex formation. For this reason, we compare the reducing power of $P$. orientalis conifers and standard antioxidants; BHA > Trolox $>\alpha$-Tocopherol $>$ BHT $>$ P.orientalis cone. The ability to reduce the ferric ions $\left(\mathrm{Fe}^{3+}\right)$ of the $P$. orientalis cone has been observed to convert the green test solution to a yellow color as seen in the results.

Cuprac method, a reduction method, is based on the principle of reducing $\mathrm{Cu}^{2+}$ to $\mathrm{Cu}^{+}$in the presence of neocuproine (Apak et al., 2006). The reduction capacity of $P$. orientalis cone $\left(20 \mu \mathrm{g} \mathrm{mL}^{-1}\right)$ is shown in Table 1 . According to the results, standard antioxidants and $\mathrm{Cu}^{2+}$ reduction capacities of $P$. orientalis cone; $\mathrm{BHA}>\mathrm{BHT}>$ Trolox $>\alpha$-Tocopherol $>P$. orientalis cone. According to these results, $P$. orientalis cone showed values especially close to $\alpha$-Tocopherol.

At the beginning of the spectroscopic methods for determining the antioxidant capacities of pure substances, plant extracts, food and beverages are the methods using $\mathrm{ABTS}^{+}$and DPPH radicals (Gulcin, 2012). A newly prepared DPPH the solution shows maximum absorbance at $517 \mathrm{~nm}$ with a dark purple color. This color disappears in the DPPH solution in the presence of antioxidant substance. The DPPH radical is a nitrogen-centered long-lived stable free radical. It is one of the most commonly used methods for determining the radical scavenging activities of antioxidant substances (Ozcelik et al., 2003). In the presence of radical antioxidant or antiradical species $\left[(\mathrm{AH})_{\mathrm{n}}\right]$ present in the medium, the DPPH free radical is converted to DPPH-H form (Gulcin, 2002). 
Table 2. $\mathrm{IC}_{50}\left(\mu \mathrm{g} \mathrm{mL}^{-1}\right)$ values for the DPPH and ABTS ${ }^{+}$ enhancement activities of the Standards and the $P$. orientalis cone

\begin{tabular}{lcc}
\hline Antioxidants & $\begin{array}{c}\text { DPPH } \\
\text { Scavenging }\end{array}$ & $\begin{array}{c}\text { ABTS }^{+} \\
\text {Scavenging }\end{array}$ \\
\hline BHA & 9.90 & 11.73 \\
BHT & 12.38 & 11.77 \\
a-Tocopherol & 12.37 & 12.11 \\
Trolox & 7.62 & 11.72 \\
P.orientalis & 24.75 & 13.42 \\
cone & & \\
\hline
\end{tabular}

It was observed that the DPPH free radical scavenging activities of standard antioxidants and $P$. orientalis cones $\left(24.75 \mu \mathrm{g} \mathrm{mL}^{-1}\right)$ were quite high. DPPH free radical scavenging activities according to the values given in Table 2 are listed as follows; Trolox $>$ BHA > $\alpha$-Tocopherol $>$ BHT $>$ P. orientalis cone.

$\mathrm{ABTS}^{++}$scavenging method was originally developed by Miller et al. (1996). ABTS $^{++}$soluble is a very useful method in organic solvents and water because it is not affected from ionic strength (Gulcin, 2012). Because it is used in wide $\mathrm{pH}$ ranges, it is a very suitable method to investigate the effect of $\mathrm{pH}$ on antioxidant mechanisms. $\mathrm{ABTS}^{++}$can react with antioxidants in foodstuffs in as short as half an hour. $\mathrm{ABTS}^{++}$has maximum absorbance at 815,734 and $414 \mathrm{~nm}$ in aqueous media and 873,414 , and $730 \mathrm{~nm}$ in alcohol media (Gulcin, 2012).

In this antioxidant method, the ABTS radical is formed. In this process, potassium persulfate $\left(\mathrm{K}_{2} \mathrm{~S}_{2} \mathrm{O}_{8}\right)$ reacts with $\mathrm{ABTS}$. This reaction forms an emerald green radical cation $\mathrm{ABTS}^{++}$and exhibits maximum absorbance at $734 \mathrm{~nm}$. The antioxidant capacity is measured according to the ability to reduce the color reaction caused by the ABTS radical (Gulcin, 2009). The $\mathrm{IC}_{50}$ values of standard antioxidants and $P$. orientalis cone ABTS radical scavenging capacity ranged from 11 to 13 $\mu \mathrm{g} \mathrm{mL} \mathrm{L}^{-1}$. The ABTS radical scavenging activity of $P$. orientalis cone was determined to have an $\mathrm{IC}_{50}$ value close to $\alpha$-Tocopherol, a standard antioxidant.

Gallic acid was used as a standard to determine total phenolic content. A standardized graph was obtained to calculate the total amount of phenolic compounds present in the ethanol extracts of $P$. orientalis cone (Absorbance $\left(\lambda_{760}\right)=0.022 \times$ [GAE], $\left.r^{2}: 0.830\right)$. Total phenolic compound amounts in the extracts were calculated as gallic acid equivalent (GAE) and in the $30 \mu \mathrm{g} \mathrm{mL}^{-1}$ extract, it was found to be $147.73 \mathrm{mg}$ GAE for $P$. orientalis cone.

Flavonoid compounds have been reported to be highly effective antioxidants. They have been found to protect against cardiovascular diseases by reducing the effect of oxidation of low-density proteins (Gulcin, 2012). Calculation was done using quercetin as a standard to determine total flavonoid content. A standard chart was created to calculate the total flavonoid content (Absorbance $\left.\left(\lambda_{415 \mathrm{~nm}}\right)=0.0045 \mathrm{x}[\mathrm{KE}], \mathrm{r}^{2}: 0.980\right)$. The total flavonoid content in the ethanol extract of the
P.orientalis cone was calculated as quercetin equivalent. These values were and $21.78 \mathrm{mgKE}$ for $P$. orientalis cones in the $30 \mu \mathrm{g} \mathrm{mL}^{-1}$ extract.

\section{Conclusion}

Phenolic substances have been identified in fruits, foliage, vegetables, seeds, shells, flowers. Such compounds have begun to be preferred for medical purposes as well as being part of the natural way of feeding. In previous times, people applied to herbal remedies to solve their health problems. The cell, the first level of defense against oxidants, is equipped with an antioxidant defense system. Antioxidants become spontaneous radicals, but they are much more stable and can't cause cellular damage. Antioxidants can match their electrons to oxidants, so they extinguish their reactivity under controlled conditions and turn them into cellular macromolecules, which makes them harmless. In a study, the total amount of flavonoid was found to be $7.06 \mathrm{mgKE}$ (Kalin, 2015). P. orientalis cones were found to have a higher total flavonoid (21.78) $\mathrm{mgKE}$ content. As a result, it was determined that the antioxidant capacities of $P$. orientalis cone were higher than the standard antioxidants. In this case, $P$. orientalis cone can be used to reduce or prevent lipid oxidation in foods, to maintain the quality of food and to extend the shelf life of medicines.

\section{References}

Apak, R., Guclu, K., Ozyurek, M., Karademir, S.E., Erca, E., 2006. The cupric ion reducing antioxidant capacity and polyphenolic content of some herbal teas, International Journal of Food Science and Nutrition, 57: 292-304.

Blois, M.S., 1958. Antioxidant deteminations by the use of a stable free radical. Nature, 26: 1199-1200.

Bursal, E., 2009. Kivi meyvesinin (Actinidia deliciosa) antioksidan ve antiradikal aktivitelerinin belirlenmesi, karbonik anhidraz enziminin saflaştırılması ve karakterizasyonu. Doktora tezi, Atatürk Üniversitesi Fen Bilimleri Enstitüsü, Erzurum.

Cakmakci, S., Topdas, E.F., Kalin, P., Han, H., Sekerci, P., Kose, L.P., Gulcin, I., 2015. Antioxidant capacity and functionality of oleaster (Elaeagnus angustifolia L.) flour and crust in a new kind of fruity ice cream, International Journal of Food Science and Technology, 50: 472-481.

Deniz, L., Serteser, A., Kargıglu, M., 2010. Uşak Üniversitesi ve yakın çevresindeki bazı bitkilerin mahalli adları ve etnobotanik özellikleri . AKÜ Fen Bilimleri Dergisi, 1: 5772.

Gulcin, I., 2002. Isırgan otunun (Urtica dioica) antioksidan aktivitesinin belirlenmesi, oksidatif enzimlerinin karakterizasyonu ve bazı in vivo etkilerinin incelenmesi, Atatürk Üniversitesi, Fen Bilimleri Enstitüsü, s114.

Gulcin, I., 2009, Antioxidant activity of L-Adrenaline: An activity-structure insight, Chemico-Biological Interaction, 179: 71-80.

Gulcin, I., 2011. Antioxidant activity of eugenol-a structure and activity relationship study, Journal of Medicinal Food, 14: 975-985. 
Gulcin, I., 2012. Antioxidant activity of food constituents: an overview, Archives of Toxicology, 86: 345-391.

Gulcin, I., Beydemir, S., Hisar, O., 2005. The effect of $\alpha$ tocopherol on the antioxidant enzymes activities and lipid peroxidation of rainbow trout (Oncorhynchus mykiss), Acta Veterinaria Hungarica, 53: 425-433.

Gulcin, I., Beydemir, S., Topal, F., Gagua, N., Bakuridze, A., Bayram, R., Gepdiremen, A., 2012. Apoptotic, antioxidant and antiradical effects of majdine and isomajdine from Vinca herbacea Waldst. and kit, J. Enzyme Inhib. Med. Chem. 27: 587-594.

Gulcin, I., Kirecc,i E., Akkemik, E., Topal, F., Hisar, O., 2010. Antioxidant and antimicrobial activities of an aquatic plant: Duckweed (Lemna minor L.), Turkish Journal of Biology, 34: 175-188.

Gulcin, I., Topal, F., Ozturk Sarıkaya, S.B., Bursal, E., Goren, A.C., Bilsel, M., 2011. Polyphenol contents and antioxidant properties of medlar (Mespilus germanica L.), Records of Natural Products, 5: 158-175.

Gülçin, İ., Elmastaş, M., Aboul-Enein, H.Y., 2007. Determination of antioxidant and radical scavenging activity of basil (Ocimum basilicum) assayed by different methodologies. Phytotherapy Research, 21: 354-361.

Halliwell, B., 1997. Antioxidants in human health and disease, Annual Review of Nutrition, 16: 33-50.

Halliwell, B., Gutteridge, J.M.C., 1990. Role of free radicals andcatalytic metal ions in human disease: an overview, Methods in Enzymology, 186: 1-85.

Kalin, P., Gulcin, I., Goren, AC., 2015. Antioxidant Activity and Polyphenol Content of Cranberries (Vaccinium macrocarpon). Records of Natural Products, 9: 496-502.

Lai, L.S., Chou, S.T., Chao, W.W., 2001. Studies on the antioxidative activities of Hsian-tsao (Mesona procumbens Hemsl) leaf gum. Journal of Agriculture Food Chemistry, 49: 963-968.

MacDonald-Wicks, L.K., Wood, L.G., Garg, M.L., 2006. Methodology for the determination of biological antioxidant capacity in vitro: a review. Journal of the Science of Food and Agriculture, 86: 2046-2056.

Miller, D.D., 1996. Minerals. In "Food Chemistry", O.R. Fennema (Ed), Marcel Dekker, New York.
Oyaizu, M., 1986. Studies on products of browning reaction prepared fromglucoseamine, Japanese Journal of Nutrition, 44: 307-314.

Ozcelik, B., Lee, J.H., Min, D.B., 2003. Effects of light, oxygen and $\mathrm{pH}$ on the 2,2-diphenyl-1-picrylhydrazyl (DPPH) method to evaluate antioxidants, Journal of Food Sciences, 68: 487-490.

Pagang, G., Miller, N., Rice-Evans, C.A., 1999. The polyphenolic content of fruits and vegetables and their antioxidant activities, What does a serving constitute? Free Radical Research, 30: 153-162.

Re, R., Pellegrini, N., Proteggente, A., Pannala, A., Yang, M., Rice-Evans, C., 1999. Antioxidant activity applying an improved ABTS radical cation decolorization assay, Free Radical Bioology and Medicine, 26: 1231-1237.

Sehitoglu, M.H., Han, H., Kalin, P., Gulcin, I., Ozkan, A., Aboul-Enein, H.Y., 2015. Pistachio (Pistacia vera L.) gum: A potent inhibitor of reactive oxygen species, Journal of Enzyme Inhibition and Medicinal Chemistry, 30: 264269.

Shahidi, F., Janitha, P.K., Wanasundara, P.D., 1992. Phenolic antioxidants, Critical Reviews in Food Science and Nutrition, 3: 67-103.

Skerget, M., Kotnik, P., Hadolin, M., Hras, A.R., Simonic, M., Knez, Z., 2005. Phenols, proanthocyanidins, flavones and flavonols in some plant materials and their antioxidant activities. Food Chemistry. 89: 191.

Sonmez, T., Keles, S., Tilki, F., 2007. Effect of aspect, tree age and tree diameter on bark thickness of Picea orientalis, Scandinavian Journal of Forest Research, 22: 193-197.

Topal, M., 2014. Bazı kinizarin türevleri: Antioksidan kapasiteleri ve karbonik anhidraz I ve II izoenzimleriüzerine inhibisyon etkileri, Doktora Tezi, Atatürk Üniversitesi, Fen Bilimleri Enstitüsü, Erzurum.

Ucarc1, H., Bilir, N., 2018. Giresun-İkisu doğu ladini (Picea orientalis (L.) link.) gençleştirme sahalarının silvikültürel değerlendirmesi. Mehmet Akif Ersoy Üniversitesi Fen Bilimleri Enstitüsü Dergisi, 1: 45-50.

Valenzuela, A.B., Nieto, S.K., 1996. Synthetic and natural antioxidants: food quality protectors, Grasas y Aceites, 47: 186-196. 